\title{
Effects of afforestation of agricultural land with grey alder (Alnus incana (L.) Moench) on soil chemical properties, comparing two contrasting soil groups
}

\author{
Oḷggerts Nikodemus ${ }^{1 *}$ (D) Dārta Kaupe ${ }^{1}$, Imants Kukul, ${ }^{1}$, Guntis Brūmelis ${ }^{2}$, Raimonds Kasparinskis ${ }^{1}$,
} lluta Dauškane ${ }^{2}$ and Agita Treimane ${ }^{2}$

\begin{abstract}
Background: Natural afforestation of former agricultural lands with alder species is common in Europe. Symbiotic nitrogen fixation by actinomycetes associated with alder species has been widely used for improvement of soil properties of abandoned agricultural lands, but relatively little is known of the interactions of these processes with soil type and chemical composition. We conducted a space-for time study with soil sampling under and outside grey alder tree canopies on two different soil groups to explore effects of colonisation of former agricultural lands by alder on soil properties.

Results: The results were analysed using analysis of variance. During the first 25 years after afforestation of former agricultural lands there was a significant increase in content of $\mathrm{C}_{\text {tot }}, \mathrm{N}_{\text {tot }}, \mathrm{K}^{+}, \mathrm{Fe}^{3+}, \mathrm{Mn}^{2+}$ and available $\mathrm{P}$ in the topsoil $(0-10 \mathrm{~cm}$ and $11-20 \mathrm{~cm})$ of Dystric Arenosols soils, which are deficient in organic matter. Such trends were not evident in organic matter rich Endostagnic Umbrisols soils, in which exchangeable $\mathrm{K}^{+}$concentration decreased and exchangeable $\mathrm{Fe}^{3+}$ and $\mathrm{Al}^{3+}$ concentration increased.

Conclusions: The results show that the effects of grey alder on soil chemical properties depend on initial soil properties. The invasion of agricultural land by grey alder leads to spatial variability of soil chemical properties creating a mosaic pattern.
\end{abstract}

Keywords: Afforestation, Grey alder, Soil properties, Umbrisols, Arenosols, Topsoil

\section{Background}

Abandonment of agricultural land and gradual overgrowing with trees and shrubs are common processes across Europe, and were particularly rapid in Eastern Europe after the collapse of the Soviet system (Prishchepov et al. 2012; Estel et al. 2015). Abandonment of agricultural practice and establishment of forest cause changes in the environment, including changes in soil. Data on changes of soil properties in some cases are

\footnotetext{
* Correspondence: olgerts.nikodemus@lu.Iv

${ }^{1}$ Faculty of Geography and Earth Sciences, University of Latvia, Jelgavas iela 1, Riga LV-1004, Latvia

Full list of author information is available at the end of the article
}

inconsistent or incomplete, and thus create a need for further research on effect of land use change on ecosystem development. In some studies an increase in soil organic carbon (SOC) stock was observed after afforestation of agricultural lands (Del Galdo et al. 2003; Hooker and Compton 2003; Mao et al. 2010; Armolaitis et al. 2013). However, there have also been cases where the SOC in soil decreased during the first years of afforestation (Ross et al. 1999; Paul et al. 2002; Chen et al. 2004). In the advanced stages of forest development, when SOC begins to accumulate in the litter horizon, the total SOC content in soil increases (Kukuls et al. 2015). During forest development, the increase in SOC

\section{Springer Open}

() The Author(s). 2020 Open Access This article is licensed under a Creative Commons Attribution 4.0 International License, which permits use, sharing, adaptation, distribution and reproduction in any medium or format, as long as you give appropriate credit to the original author(s) and the source, provide a link to the Creative Commons licence, and indicate if changes were made. The images or other third party material in this article are included in the article's Creative Commons licence, unless indicated otherwise in a credit line to the material. If material is not included in the article's Creative Commons licence and your intended use is not permitted by statutory regulation or exceeds the permitted use, you will need to obtain permission directly from the copyright holder. To view a copy of this licence, visit http://creativecommons.org/licenses/by/4.0/. 
content is accompanied by an increase in soil nitrogen content (Li et al. 2012; Holubík et al. 2014). Other studies have reported a decrease in magnesium $(\mathrm{Mg})$, calcium $(\mathrm{Ca})$ and potassium $(\mathrm{K})$ concentration in soil, which may affect soil fertility and thus productivity of tree stands (Berthrong et al. 2009). There are inconsistent results on changes in phosphorous (P) levels after land transformation (MacDonald et al. 2012; Deng et al. 2016). After afforestation, the content and behaviour of $\mathrm{P}$ forms in soil differ within former agricultural lands, depending on soil properties. Changes in labile P content after afforestation were reported to depend on soil characteristics like clay content and $\mathrm{pH}$, while changes in total P were not observed (MacDonald et al. 2012). Changes in SOC and nutrient element content in soil during forest development depend on other factors like previous land use (grasslands, herbaceous plants, etc.), soil tillage and cultivation, tree species, tree stand age, relief, climate and soil properties like clay content and pH value (Paul et al. 2002; Jandl et al. 2007; Laganière et al. 2010; Uri et al. 2014; Cukor et al. 2017). Afforestation of agricultural land with deciduous trees like alder (Alnus) species is common in temperate (Anthelem et al. 2001) and hemi-boreal biomes of Europe (Uri et al. 2011). It is considered that afforestation of abandoned lands with grey alder has a potential to increase biomass supply and carbon $(C)$ capture in northern Europe. It is well known that grey alder (Alnus incana (L.) Moench) in symbiosis with Frankia group Actinomycetes captures nitrogen from the atmosphere and litter deposition causes accumulation of nitrogen $(\mathrm{N})$ in soil, along with increase of organic carbon content (Bārdule and Lazdinšs 2010; Uri et al. 2011, 2014). Soil conditions can also affect accumulation of $\mathrm{C}, \mathrm{N}$ and other chemical elements. Therefore, the aim of the study was to determine changes in soil properties during the natural afforestation of abandoned agricultural lands with grey alder, depending on soil group. We paid attention to development of spatial heterogeneity of soil properties during the afforestation from concentric tree patches.

\section{Materials and methods \\ Characteristics of study site}

The study was conducted in the central part of Latvia, in Vidzeme upland (Fig. 1). Mean annual precipitation in Latvia is $750-800 \mathrm{~mm}$, of which about $500 \mathrm{~mm}$ falls in warm seasons. Mean temperature during the warm period is $16.9^{\circ} \mathrm{C}$ and $5.4{ }^{\circ} \mathrm{C}$ during the cold period. Mean snow depth is $22-26 \mathrm{~cm}$ (Briede and Korelska 2018). The study territory is located in the hemiboreal forest zone (Ahti et al. 1968). The landscape of the study territory is a mosaic of agricultural land, forests dominated by spruce, pine, birch and aspen, and former agricultural land mostly overgrown by grey alder and spruce (Ruskule et al. 2016).

Arenosols, Podzols, Cambisols, Retisols, Luvisols, Stagnosols, Gleysols, Umbrisols and Histosols are the most dominant soils in the studied region, which formed on glacigenic (loam, sandy loam and sand), glaciofluvial (sand, coarse sand) and peat deposits (Kasparinskis et al. 2017). Afforestation with grey alder was studied in two sites. In one, Dystric Arenosols formed on glacigenic deposits of loamy sand in the soil parent material and sand in the topsoil. In the other, afforestation occurred on Endostagnic Umbrisols formed by loamy sand in topsoil, and loam, silt loam and sandy loam in soil parent material. The depth of the Ap horizon varied from 24 to 40 $\mathrm{cm}$ in the Arenosols, and from 30 to $50 \mathrm{~cm}$ in the Umbrisols. Agricultural practice in both sites was

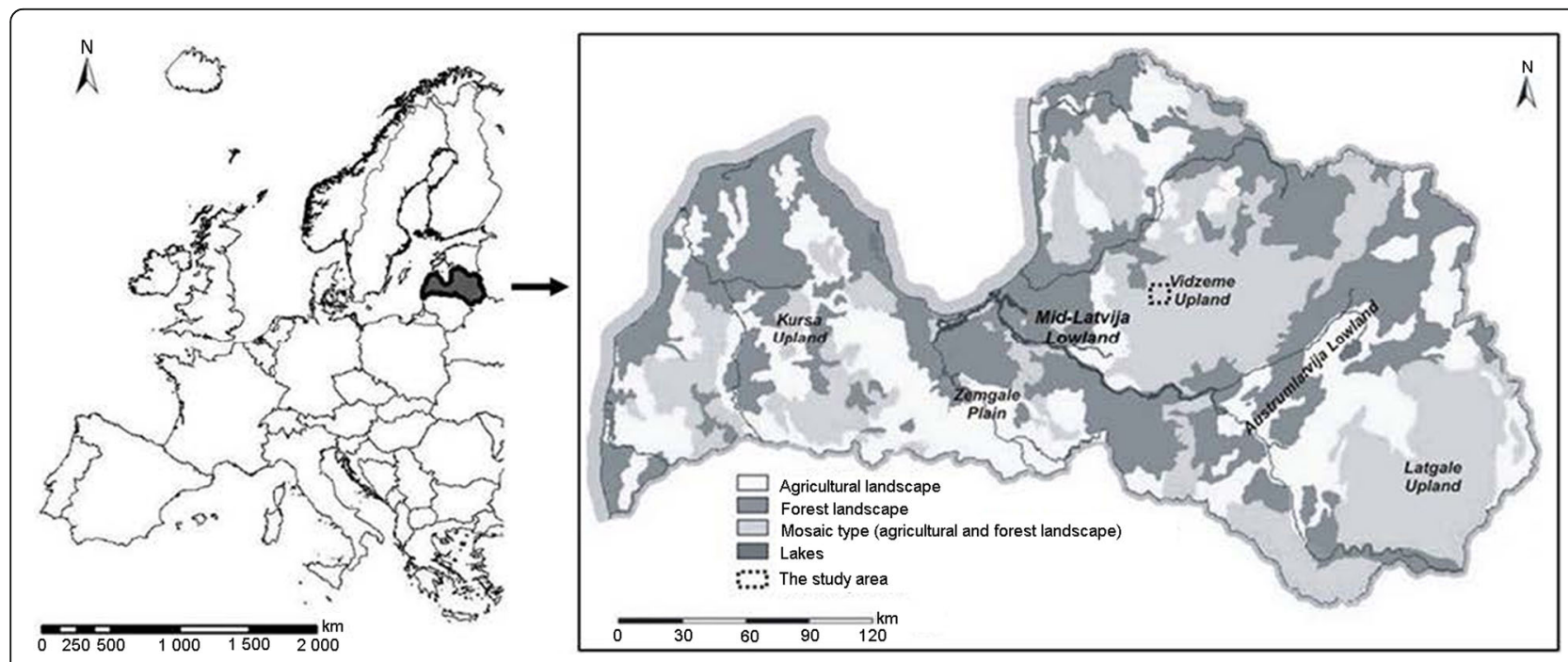

Fig. 1 Location of the study area 
discontinued in the mid-1990s. Historically these lands were managed as meadows and croplands.

\section{Study methods}

Three patches of grey alder were selected in each territory delineated by a soil group. We selected tree patches that contained only grey alder. The mean area of grey alder patches was $81 \mathrm{~m}^{2}$. Lists of plants species were made within and just outside $(2-3 \mathrm{~m})$ the selected tree patches prior to soil sampling. Age of the grey alder trees was determined from tree cores obtained with a Presler's auger.

Soil textural classes were determined according to FAO Guidelines for Soil Description (Jahn et al. 2006). Soil profiles were described and soil groups were determined according to the international WRB soil classification (IUSS Working Group WRB 2015).

Soil samples for chemical analysis were collected at the centre of patches, and at distances of 2 and $4 \mathrm{~m}$ in north, east, south and west directions from the centre to the edges of the patches (Fig. 2). The patch edges were only recently colonised and this zone contained only a few small alder trees. Control samples were collected in the grassland 1-2 $\mathrm{m}$ outside the tree crown and alder rooting zone, at a distance about 3-4 $\mathrm{m}$ from the sample located at $4 \mathrm{~m}$ from the patch centre. Soil samples were collected from small pits with size $20 \mathrm{~cm} \times 20 \mathrm{~cm}$ at depths $0-10 \mathrm{~cm}$ and $11-20 \mathrm{~cm}$. In each grey alder patch, the soil profile was described in pits. A total of 32 soil samples were collected from each alder patch.

Three replicates were taken from each collected soil sample and analysed in the soil laboratory of the University of Latvia Faculty of Geography and Earth Sciences. Air dried samples were broken up and sieved through a 2-mm mesh. Particle sizes were determined by pipette analysis (van Reeuwijk 1995; Cools and De Vos 2010), $\mathrm{pH}$ value was measured with an "Adrona $\mathrm{pH}$ meter

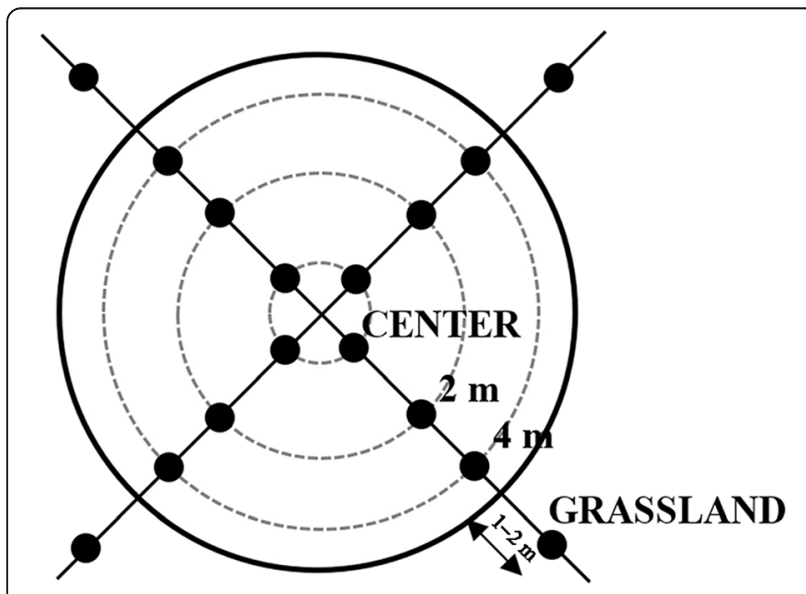

Fig. 2 Scheme of sampling site positions in the wood patch
AM1605" in $1 \mathrm{~mol} \cdot \mathrm{L}^{-1} \mathrm{BaCl}_{2}$ solution (Tan 2005; Cools and De Vos 2010), content of total carbon $\left(C_{\text {tot }}\right)$ and total nitrogen $\left(\mathrm{N}_{\text {tot }}\right)$ was determined by an "EuroVector EuroEA" analyser (Tan 2005; Cools and De Vos 2010) and content of exchangeable cations $\left(\mathrm{Ca}^{2+}, \mathrm{Mg}^{2+}, \mathrm{K}^{+}, \mathrm{Fe}^{3+}\right.$, $\mathrm{Al}^{3+}$ ) in $1 \mathrm{~mol} \cdot \mathrm{L}^{-1} \mathrm{BaCl}_{2}$ solution by an atomic absorption spectrometer "Perkin Elmer Analyst 200" (Tan 2005; Cools and De Vos 2010). Available phosphorous ( $\left.\mathrm{P}_{1}\right)$ content was determined by Mehlich 3 extraction method with an "Thermo Scientific iCAP7000 ICP-OES" spectrometer (Gutiérrez Boem et al. 2011; AgroEcoLab 2016).

\section{Data analysis}

The Shapiro-Wilk test was used to test for normal distributions. For statistical analysis, data on soil physical and chemical properties not conforming to normal distribution $\left(\mathrm{pH}_{\mathrm{BaCl}_{2}}, \mathrm{~N}_{\text {tot }}, \mathrm{K}^{+}, \mathrm{Fe}^{3+}\right.$ and $\left.\mathrm{Al}^{3+}\right)$ underwent lognormal distribution transformation. Firstly, main and interaction effects of soil, horizon and location under the canopy were tested by 3-way ANOVA. Then, statistically significant $(p<0.05)$ differences between soil types for each soil horizon in the grassland (control) sites were determined by Tukey's one-way ANOVA. A one-way ANOVA with Tukey's post hoc test was used to test for significant differences in soil properties between locations for each soil type and horizon. SPSS PASW Statistics 18 software was used for the analysis.

\section{Results}

Tree patches

Tree age in the centre of the patches was up to 20 to 25 years and the youngest trees (4 to 10 years old) were at the edges, demonstrating concentric vegetative spread around trees that colonised by seed. Average height of trees in the centre of the patches was $13.2 \pm 0.5 \mathrm{~m}$ on sandy Dystric Arenosols and $12.2 \pm 0.6 \mathrm{~m}$ on sandy loam Endostagnic Umbrisols. Average diameter of these trees was $16.2 \pm 0.7 \mathrm{~cm}$ and $14.8 \pm 0.7 \mathrm{~cm}$, respectively. Height and diameter of the trees gradually decreased from centre to the edges of patches. Vegetation in the study site on Arenosols was dominated by Elytrigia repens, Dactylis glomerata and Festuca ovina, and on Umbrisols soil by Elytrigia repens, Aegopodium podagraria, Vicia cracca and other plants (Table 1).

\section{Descriptive statistics}

Three-way ANOVA indicated significant main effects of soil, horizon and location on chemical properties, except for soil on $\mathrm{N}_{\text {tot }}$ and location on $\mathrm{Ca}^{2+}$ and $\mathrm{pH}$ (Table 2). Significant interaction effects of soil horizon occurred for $\mathrm{N}_{\text {tot }}, \mathrm{K}^{+}, \mathrm{Ca}^{2+}, \mathrm{Al}^{3+}$ and $\mathrm{pH}$, and of soil location for $\mathrm{N}_{\text {tot }}, \mathrm{C}_{\text {tot }}, \mathrm{P}, \mathrm{Mg}^{2+}, \mathrm{K}^{+}$and $\mathrm{Al}^{3+}$. For the grassland sampling sites, which can indicate soil properties before tree 
Table 1 Characterisation of the dominant vegetation in the study sites, listed by decreasing cover

\begin{tabular}{|c|c|c|c|}
\hline \multicolumn{2}{|c|}{ Vegetation in sandy Dystric Arenosols site } & \multicolumn{2}{|c|}{ Vegetation in sandy loam Endostagnic Umbrisols site } \\
\hline Grassland & Grey alder stand & Grassland & Grey alder stand \\
\hline $\begin{array}{l}\text { 1. Elytrigia repens } \\
\text { 2. Festuca ovina } \\
\text { 3. Dactylis glomerata } \\
\text { 4. Rhytidiadelphus squarrosus } \\
\text { 5. Knautia arvensis } \\
\text { 6. Aegopodium podagraria } \\
\text { 7. Galium mollugo } \\
\text { 8. Poa sp. }\end{array}$ & $\begin{array}{l}\text { 1. Elytrigia repens } \\
\text { 2. Aegopodium podagraria } \\
\text { 3. Poa sp. } \\
\text { 4. Galium mollugo } \\
\text { 5. Festuca ovina } \\
\text { 6. Veronica chamaedrys }\end{array}$ & $\begin{array}{l}\text { 1. Elytrigia repens } \\
\text { 2. Vicia cracca } \\
\text { 3. Aegopodium podagraria } \\
\text { 4. Dactylis glomerata } \\
\text { 5. Equisetum sylvaticum } \\
\text { 6. Galium album } \\
\text { 7. Geranium palustre } \\
\text { 8. Phleum pratense } \\
\text { 9. Veronica chamaedrys }\end{array}$ & $\begin{array}{l}\text { 1. Galium album } \\
\text { 2. Valeriana officinalis } \\
\text { 3. Aegopodium podagraric } \\
\text { 4. Campanula patula } \\
\text { 5. Dactylis glomerata } \\
\text { 6. Equisetum sylvaticum } \\
\text { 7. Veronica chamaedrys }\end{array}$ \\
\hline
\end{tabular}

colonisation, there were no significant differences (1-way ANOVA) in $\mathrm{N}_{\text {tot }}$ content between Dystric Arenosols and Endostagnic Umbrisols (Table 3). Sandy Arenosols had higher $\mathrm{pH}_{\mathrm{BaCl}_{2}}$ and $\mathrm{Mg}^{2+}$ and $\mathrm{Fe}^{3+}$ and $\mathrm{Al}^{3+}$ content, while $\mathrm{C}_{\text {tot }}$ and $\mathrm{P}$ content was higher in sandy loam Endostagnic Umbrisol soil.

\section{Effect of location under the tree canopy}

One-way ANOVA for each soil type and soil layer showed that soil $\mathrm{pH}_{\mathrm{BaCl}_{2}}, \mathrm{Ca}^{2+}$ and $\mathrm{Mg}^{2+}$ content after 25 years of afforestation. $\mathrm{N}_{\text {tot }}$ content in topsoil (1-10 $\mathrm{cm}$ layer) was significantly higher (by 29.4\%) in the centre of the grey alder patches on sandy Dystric Arenosol soil than in the periphery of wood patches and in grassland (Fig. 3a). In the deeper $11-20 \mathrm{~cm}$ soil layer, the difference in $\mathrm{N}_{\text {tot }}$ content was greater, being $60 \%$ higher in the patch centre than in the grassland. In loamy clay Endostagnic Umbrisol soil, the $\mathrm{N}_{\text {tot }}$ content did not significantly differ between sampling sites (Fig. 3a). In all studied sites $\mathrm{N}_{\text {tot }}$ content in the top layer of the Ap horizon $(0-10 \mathrm{~cm})$ was higher than in the deeper layer $(11-20 \mathrm{~cm})$.

$C_{\text {tot }}$ content in the $0-10 \mathrm{~cm}$ and $11-20 \mathrm{~cm}$ layers of the sandy Dystric Arenosols was significantly higher at the centre of tree patches than in sampling sites closer to the edges and grasslands (Fig. 3b). Afforestation with grey alder increased $C_{\text {tot }}$ content by $37.9 \%$ in the $0-10$ $\mathrm{cm}$ and by $88.1 \%$ in the $11-20 \mathrm{~cm}$ layer. However, $C_{\text {tot }}$ content did not significantly differ between sampling locations in the sandy loam Endostagnic Umbrisols (Fig. $3 \mathrm{~b})$. Both of the studied soils had higher $\mathrm{C}_{\text {tot }}$ content in the $0-10 \mathrm{~cm}$ layer compared to the $11-20 \mathrm{~cm}$ layer.

Soil in the centre of tree patches in sandy Dystric Arenosols also had significantly higher $\mathrm{K}^{+}$content than in the periphery and grassland (Fig. $3 \mathrm{c}$ ). $\mathrm{K}^{+}$content of soil in the centre of wood patch was two times higher than in the grassland. This spatial pattern was not observed for the Endostagnic Umbrisols. Mean content of P in the $0-10 \mathrm{~cm}$ layer in the centre of patches was higher than in the grassland for both soils (Fig. 3d), but this difference was significant (by $84.9 \%$ ) only for sandy Dystric Arenosols.

The only significant difference in $\mathrm{Fe}^{3+}$ concentration between sampling sites was observed in Endostagnic Umbrisols in the $0-10 \mathrm{~cm}$ layer, where $\mathrm{Fe}^{3+}$ concentration in the centre of wood patch was higher by about $140 \%$ than in the other sites (Fig. 4a). Aluminium was the only studied element that had higher content in the deeper layer $(11-20 \mathrm{~cm})$ than in the top layer $(0-10 \mathrm{~cm})$ (Fig. 4b). In Endostagnic Umbrisols, the $\mathrm{Al}^{3+}$ concentration in the $11-20 \mathrm{~cm}$ layer tended to be higher toward the patch centre (Fig. 4b).

\section{Discussion}

The observed interaction of soil and horizon effects was not surprising considering impact of soil texture on soil chemistry and processes (Vanmechelen et al. 1997). However, the significant interaction effect of soil and

Table 2 Three-way ANOVA effects of soil, horizon and location under grey alder canopy on soil chemistry

\begin{tabular}{|c|c|c|c|c|c|c|c|c|c|c|}
\hline Effects & $\mathrm{N}_{\text {tot }}$ & $C_{\text {tot }}$ & $P$ & $\mathrm{Mg}^{2+}$ & $\mathrm{K}^{+}$ & $\mathrm{Ca}^{2+}$ & $\mathrm{Al}^{3+}$ & $\mathrm{Fe}^{3+}$ & $\mathrm{Mn}^{2+}$ & $\mathrm{pH}$ \\
\hline Soil & n.s. & $* * *$ & $* * *$ & $* * *$ & $* * *$ & $* * *$ & $* * *$ & $* * *$ & $* * *$ & *** \\
\hline Horizon & $* * *$ & $* * *$ & $* * *$ & $* * *$ & $* * *$ & $* * *$ & $* * *$ & $* *$ & $* * *$ & $* * *$ \\
\hline Location & $* * *$ & $* * *$ & * & $*$ & $* * *$ & n.s. & $* * *$ & $* * *$ & $* * *$ & n.s. \\
\hline Soil $\times$ Horizon & * & n.s. & n.s. & n.s. & * & $* * *$ & ** & n.s. & n.s. & ** \\
\hline Soil $\times$ location & ** & * & * & $* * *$ & $* * *$ & n.s. & $* * *$ & n.s. & n.s. & n.s. \\
\hline Horizon $\times$ location & n.s. & n.s. & n.s. & n.s. & n.s. & n.s. & n.s. & n.s. & n.s. & n.s. \\
\hline Soil $\times$ Horizon $\times$ location & n.s. & n.s. & n.s. & n.s. & n.s. & n.s. & n.s. & n.s. & n.s. & n.s. \\
\hline
\end{tabular}

$p$ values are shown: ${ }^{*} p<0.05 ;{ }^{* *} p<0.01 ;{ }^{* * *} p<0.001 ;$ n.s. not significant 


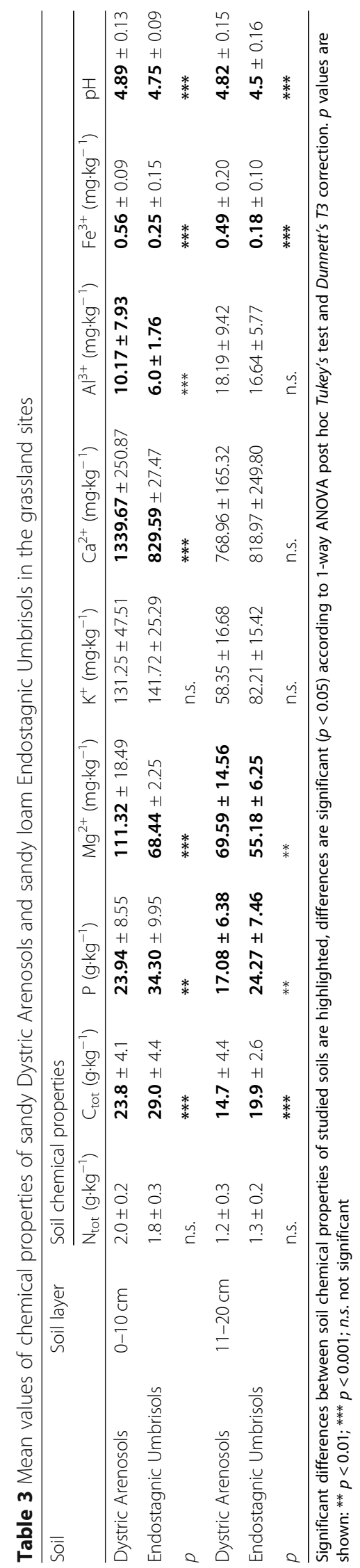



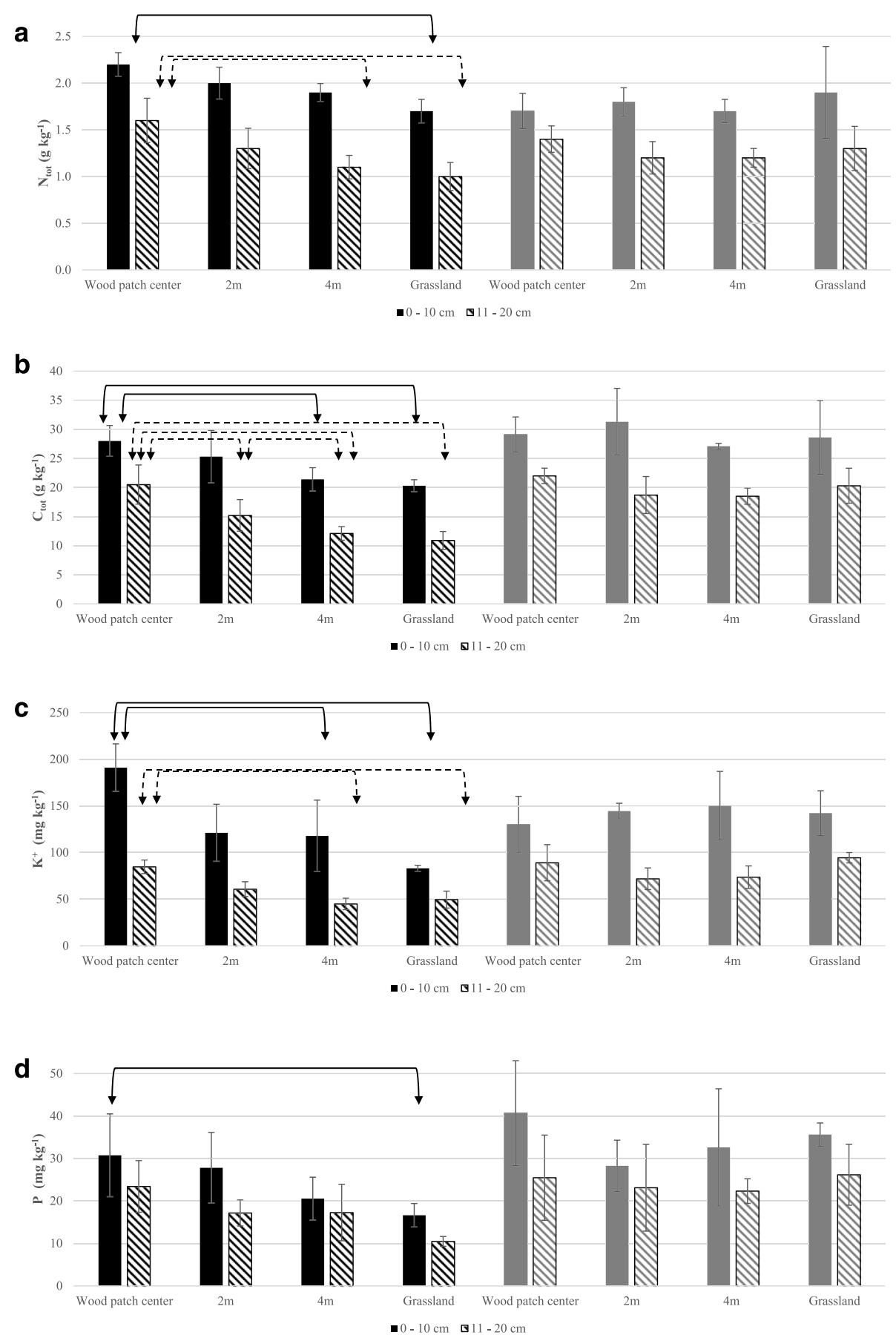

Fig. $3 \mathrm{~N}_{\text {tot }}(\mathbf{a}), \mathrm{C}_{\text {tot }}(\mathbf{b}), \mathrm{K}^{+}(\mathbf{c})$ and $\mathrm{P}(\mathbf{d})$ content in sandy Dystric Arenosols (black bars) and loamy clay Endostagnic Umbrisols (grey bars) in the 0-10 cm and 11-20 cm layers. Explanation of sampling location: Centre - centre of the patch; $2 \mathrm{~m}-2 \mathrm{~m}$ away from the centre; $4 \mathrm{~m}-4 \mathrm{~m}$ away from the centre; grassland. Arrows identifies that differences in chemical element content are significant $(p<0.05)$ according to Tukey's test and Dunnett's T3 correction

location under the tree canopy clearly shows the importance of soil type in understanding of the role of grey alder in afforestation. The space-for time study clearly showed impact of afforestation by grey alder on soil properties, with the effect being stronger in the centre of tree patches where colonisation was initiated, and weaker toward the edges where trees were younger.

Sandy Dystric Arenosols, which are relatively poor in nutrients $\left(\mathrm{P}\right.$ and $\left.\mathrm{K}^{+}\right)$and organic matter, accumulated carbon and nutrient elements (nitrogen, potassium, 


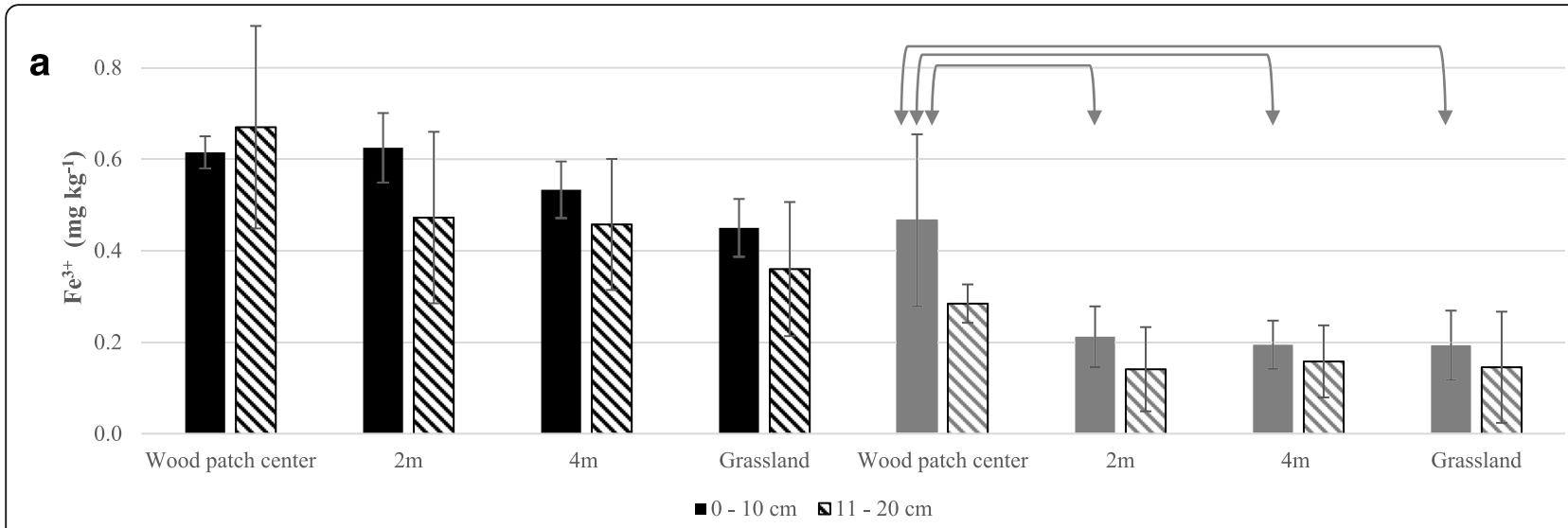

b

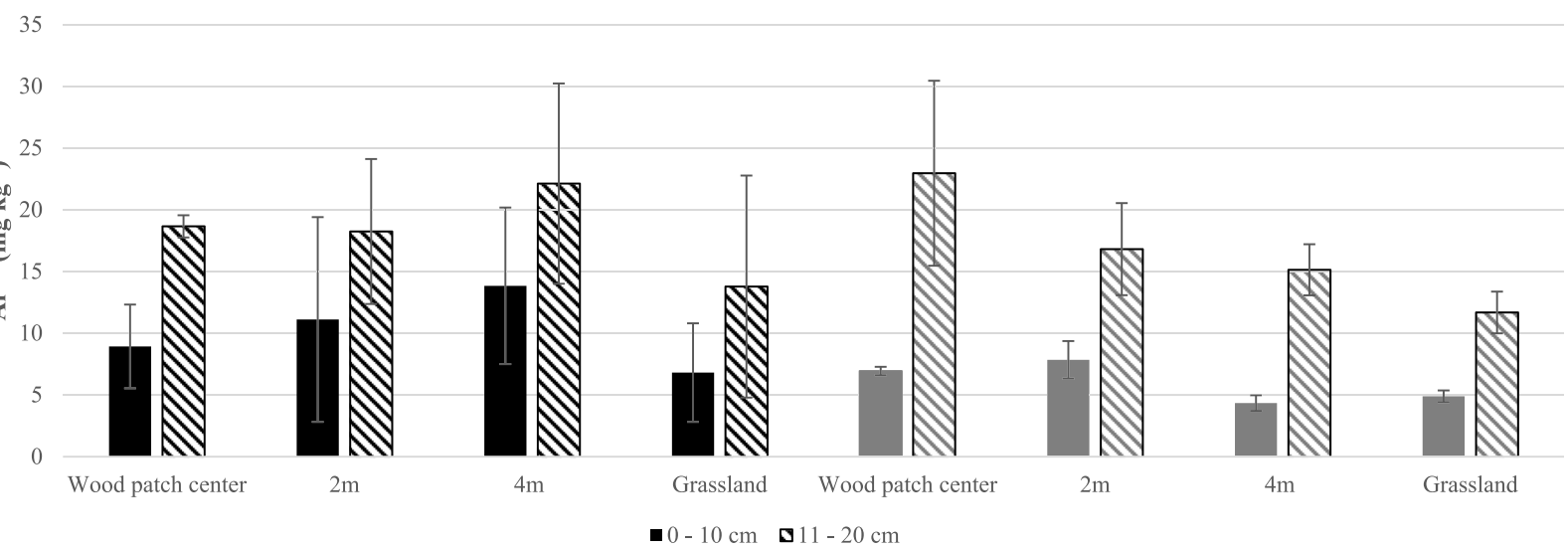

Fig. $4 \mathrm{Fe}^{3+}(\mathbf{a})$ and $\mathrm{Al}^{3+}$ (b) concentrations in sandy Dystric Arenosols soil (black bars) and loamy clay Endostagnic Umbrisols soil (gray bars) in the $0-10 \mathrm{~cm}$ and $11-20 \mathrm{~cm}$ layers. Explanation of sampling location: Centre - centre of the patch; $2 \mathrm{~m}-2 \mathrm{~m}$ away from the centre; $4 \mathrm{~m}-4 \mathrm{~m}$ away from the centre; grassland. Arrows identifies that differences in chemical element content are significant $(p<0.05)$ according to Tukey's test and Dunnett's T3 correction

phosphorous) during the afforestation of grasslands at a higher rate than in the more fertile Endostagnic Umbrisols. Many other studies have reported the role of grey alder afforestation in soil enrichment with nitrogen (Uri et al. 2014; Innangi et al. 2017; Morozov et al. 2018) and carbon (Uri et al. 2017). The changes in topsoil (0-10 $\mathrm{cm})$ are caused by the accumulation of alder leaf litter and formation of easy decomposable and nitrogen-rich biomass (Innangi et al. 2017). The development of rootnodule symbioses with Frankia in roots of alder (HussDanell and Lundmark 1988) is affected by soil properties like $\mathrm{pH}$ value and nitrogen content. Increased nitrogen content in soil can affect nodulation of Frankia causing decreased nitrogen accumulation (Bond et al. 1954). In our case, there were no differences between the studied soils in $\mathrm{N}$ content in grassland, suggesting that this factor did not cause differences between the soil types in $\mathrm{N}$ fixation and uptake with plant roots. In contrast to the Dystric Arenosols soils, Endostagnic Umbrisols soil in grassland had significantly higher $\mathrm{C}_{\text {tot }}, \mathrm{P}$ and $\mathrm{K}^{+}$content. Experimental studies have shown that nitrogen fixation by grey alder can be affected by phosphorous and potassium content in soil (Ekblad and Huss-Danell 1995). Low soil $P$ availability limits $\mathrm{N}_{2}$ fixation in alder stands (Uliassi and Ruess 2002), while high P content in soil has an positive effect on nodulation and $\mathrm{N}_{2}$-fixation rate (Ekblad and Huss-Danell 1995; Uliassi and Ruess 2002; Gentili and Huss-Danell 2003). In our study more rapid accumulation of $\mathrm{N}_{\text {tot }}$ and available $\mathrm{P}$ in soil after afforestation of agricultural lands with grey alder occurred in the soil type with lower phosphorus content (Fig. 3a and d).

Part of the nitrogen released from alder leaf litter may have been taken up by the herb layer plants under the tree canopy. This might have caused part of the differences in $\mathrm{N}$ accumulation in soil between the soil groups. The herb layer was visually denser on the richer Endostagnic Umbrisols, but we did not investigate nitrogen uptake by herb layer plants. Previously, it has been reported that nitrogen accumulation by plants can cause a decrease in soil nitrogen content (Miletić et al. 2012; Podwika et al. 2018) after afforestation.

Our results showed that leaf litter accumulation not only had significant effect on $\mathrm{N}$ accumulation in soil, but 
also on $\mathrm{K}^{+}$and available $\mathrm{P}$ content in the upper layer of soil (Fig. $3 \mathrm{c}$ and $\mathrm{d}$ ). The decreased $\mathrm{K}_{\text {exch }}$ content in the centre of alder patches in the Endostagnic Umbrisols soils might be due to herb layer plant uptake. The observed $\mathrm{P}$ accumulation in soil after afforestation with grey alder has also been reported in other studies (Uri et al. 2003; Taleshi et al. 2009), which can be explained by microbiological and mycorrhizal activity (Ingestad 1987; Giardina et al. 1995; Arveby and Granhall 1998). Alder has also been reported to increase availability of phosphorus via root secretion of phosphate enzymes (Giardina et al. 1995). However, the increase in available P content was statistically significant only in the sandy Dystric Arenosols and not in the Endostagnic Umbrisols.

The increased $\mathrm{Al}^{3+}$ concentration in the centre of grey alder patches in the deeper horizon of Endostagnic Umbrisols might be due to root exudates that indirectly affect soil reaction by solubilising unavailable aluminium (Skyllberg 1996). However, in our study a significant change in $\mathrm{pH}$ value was not observed in topsoil after afforestation with grey alder. The literature contains contrasting reports on effect of alder afforestation on soil $\mathrm{pH}$ value. In some cases afforestation with grey alder has been observed to cause soil acidification (Uri et al. 2014; Podwika et al. 2018), while other studies showed an increase of soil reaction and exchangeable base content (Huss-Danell and Lundmark 1988).

During the afforestation of grasslands with grey alder high spatial heterogeneity in soil properties was found, indicated by significant differences between tree patches and grassland, and also within tree patches. However, with creation of a closed cover of alder over time, the soil properties in grassland can be expected to converge. Formation of soil properties after afforestation is also affected by soil bacterial communities (Preem et al. 2012), and the developmental trajectories of these may differ depending on soil properties. Further studies are needed in soil ecology to evaluate effect of tree roots on soil physical properties, moisture conditions, biochemical and other processes.

\section{Conclusions}

The results showed increased content of $\mathrm{C}_{\text {tot }}, \mathrm{N}_{\text {tot }}$, available $\mathrm{P}$ and exchangeable $\mathrm{K}^{+}$concentration in topsoil after afforestation of agricultural lands with grey alder (Alnus incana (L.) Moench) during the time span of 25 years on sandy soils poor in organic matter soils. The effect in more fertile soils with higher organic matter content was less evident and might have been confounded by herb layer plant uptake. Afforestation of agricultural lands with grey alder had effects on physical-chemical and biochemical processes in soils: increased $\mathrm{P}$ availability to plants in soil, and changes in $\mathrm{Al}^{3+}$ and $\mathrm{Fe}^{3+}$ ion mobility. Our results show that initial soil properties in grasslands significantly interact with effects due to afforestation with grey alder, which adds complexity to producing models of biogeochemical processes and creates difficulty in extrapolation of results to other soil types to guide land management.

Mosaic type afforestation was shown to create higher spatial variability of soil properties, which needs to be considered during soil mapping and in choosing the correct mapping scale.

\section{Abbreviations \\ $C_{\text {tot: }}$ Total carbon; $\mathrm{N}_{\text {tot }}$ : Total nitrogen; SOC: Soil organic carbon; $\mathrm{Ca}^{2+}, \mathrm{Mg}^{2+}$ $\mathrm{K}^{+}, \mathrm{Fe}^{3+}, \mathrm{Al}^{3+}$ : Exchangeable cations.}

\section{Acknowledgments}

Not applicable.

\section{Authors' contributions}

Study concept and design: Nikodemus O, Kaupe D, Brūmelis G. Analysis and interpretation of data: Kaupe D, Kuku!s I, Dauškane I, Treimane A. Drafting of the manuscript: Nikodemus $\mathrm{O}$, Kaupe D. Critical revision of the manuscript for important intellectual content: Kuku!̣s I, Brūmelis G, Kasparinskis R. Statistical analysis: Kaupe D, Kasparinskis R. Obtained funding: Nikodemus O. Study supervision: Nikodemus O. The author(s) read and approved the final manuscript.

\section{Funding}

The study was supported by University of Latvia grant Nr. AAp2016/B041// Zd2016/AZ03 within the project "Climate change and sustainable use of natural resources".

Availability of data and materials

Research data are not shared.

Ethics approval and consent to participate

Not applicable.

Consent for publication

Not applicable.

Competing interests

The authors declare that there are no competing interests.

\section{Author details}

${ }^{1}$ Faculty of Geography and Earth Sciences, University of Latvia, Jelgavas iela 1, Riga LV-1004, Latvia. ${ }^{2}$ Faculty of Biology, University of Latvia, Jelgavas iela 1, Riga LV-1004, Latvia.

Received: 20 December 2019 Accepted: 9 June 2020

Published online: 19 June 2020

References

AgroEcoLab (2016) Melinch 3 extraction protocol. http://www.agroecologylab. com/uploads/2/7/2/8/27281831/mehlich3_extraction.pdf. Accessed 20 Dec 2019

Ahti T, Hämet-Ahti L, Jalas J (1968) Vegetation zones and their sections in northwestern Europe. Ann Bot Fenn 5(3):169-211

Anthelem F, Grossi J-L, Brun J-J, Didier L (2001) Consequences of green alder expansion on vegetation changes and arthropod communities removal in thenorthern French Alps. Forest Ecol Manag 145:57-65

Armolaitis K, Aleinikovienẻ J, Lubytė J, Žèkaitė V, Garbaravičius P (2013) Stability of soil organic carbon in agro and forest ecosystems on Arenosol. Zemdirbyste 100(3):227-234. https://doi.org/10.13080/z-a.2013.100.029

Arveby AS, Granhall U (1998) Occurrence and succession of mycorrhizas in Alnus incana. Swed J Agric Res 28:117-127

Bärdule A, Lazdinš A (2010) Accumulation of carbon and nitrogen in mineral soils in grey alder (Alnus incana (L.) Moench) stands on naturally afforested farmlands. Mežzinătne 21(54):95-109 
Berthrong ST, Jobbágy EG, Jackson RB (2009) A global meta-analysis of soil exchangeable cations, $\mathrm{pH}$, carbon, and nitrogen with afforestation. Ecol Appl 19(8):2228-2241. https://doi.org/10.1890/08-1730.1

Bond G, Fletcher WW, Ferguson TP (1954) The development and function of the root nodules of Alnus, Myrica and Hippophaë. Plant Soil 5(4):309-323. https:// doi.org/10.1007/BF01354455

Briede A, Korel̦ska L (2018) Klimatisko rādītāju reǵionālās atšk̦irības. In: Nikodemus O, Klavinšs M, Krisjāne Z, Zelčs V (eds) Latvija: Zeme, Daba, Tauta, Valsts. Latvijas Universitātes Akadēmiskais apgāds, Rīga, pp 231-245

Chen CR, Xu ZH, Mathers NJ (2004) Soil carbon pools in adjacent natural and plantation forests of subtropical Australia. Soil Sci Soc Am J 68(1):282-291. https://doi.org/10.2136/sssaj2004.2820

Cools N, De Vos B (2010) Sampling and analysis of soil. Manual part X. In: Manual on methods and criteria for harmonized sampling, assessment, monitoring and analysis of the effects of air pollution on forests. UNECE, ICP Forests, Hamburg, p 208

Cukor J, Vacek Z, Linda R, Bílek L (2017) Carbon sequestration in soil following afforestation of former agricultural land in the Czech Republic. Cent Eur For J 63:97-104. https://doi.org/10.1515/forj-2017-0011

Del Galdo I, Six J, Peressotti A, Francesca Cotrufo M (2003) Assessing the impact of land-use change on soil $\mathrm{C}$ sequestration in agricultural soils by means of organic matter fractionation and stable C isotopes. Glob Chang Biol 9(8): 1204-1213. https://doi.org/10.1046/j.1365-2486.2003.00657.x

Deng Q, McMahon DE, Xiang Y, Yu C-L, Jackson RB, Hui D (2016) A global metaanalysis of soil phosphorus dynamics after afforestation. New Phytol 213:181192. https://doi.org/10.1111/nph.14119

Ekblad ALF, Huss-Danell K (1995) Nitrogen fixation by Alnus incana and nitrogen transfer from $A$. incana to Pinus sylvestris influenced by macronutrients and ectomycorrhiza. New Phytol 131(4):453-459. https://doi.org/10.1111/j.14698137.1995.tb03082x

Estel S, Kuemmerle T, Alcántara C, Levers C, Prishchepov A, Hostert P (2015) Mapping farmland abandonment and recultivation across Europe using MODIS NDVI time series. Remote Sens Environ 163:312-325. https://doi.org/ 10.1016/J.RSE.2015.03.028

Gentili F, Huss-Danell K (2003) Local and systemic effects of phosphorus and nitrogen on nodulation and nodule function in Alnus incana. J Exp Bot 54(393):2757-2767. https://doi.org/10.1093/jxb/erg311

Giardina CP, Huffman S, Binkley D, Caldwell BA (1995) Alders increase soil phosphorus availability in a Douglas-fir plantation. Can J For Res 25(10):16521657

Gutiérrez Boem FH, Rubio G, Barbero D (2011) Soil phosphorus extracted by bray 1 and Mehlich 3 soil tests as affected by the soil/solution ratio in Mollisols. Commun Soil Sci Plant Anal 42(2):220-230. https://doi.org/10.1080/00103624. 2011.535072

Holubík O, Podrázský V, Vopravil J, Khel T, Remeš J (2014) Effect of agricultural lands afforestation and tree species composition on the soil reaction, total organic carbon and nitrogen content in the uppermost mineral soil profile. Soil Water Res 9:192-200. https://doi.org/10.17221/104/2013-SWR

Hooker TD, Compton JE (2003) Forest ecosystem carbon and nitrogen accumulation during the first century after agricultural abandonment. Ecol Appl 13(2):299-313. https://doi.org/10.1890/1051-0761(2003)013[0299: FECANA]2.0.CO;2

Huss-Danell K, Lundmark J (1988) Growth of nitrogen-fixing Alnus incana and Lupinus spp. for restoration of degenerated forest soil in northern Sweden. Faculty of Forestry, Swedish University of Agricultural Sciences, Uppsala

Ingestad T (1987) New concepts on soil fertility and plant nutrition as illustrated by research on forest trees and stands. Geoderma 40(3-4):237-252. https:// doi.org/10.1016/0016-7061(87)90035-8

Innangi M, Danise T, d'Alessandro F, Curcio E, Fioretto A (2017) Dynamics of organic matter in leaf litter and topsoil within an Italian Alder (Alnus cordata (Loisel.) Desf.) ecosystem. Forests 8:240. https://doi.org/10.3390/f8070240

IUSS Working group WRB (2015) World reference base for soil resources 2014, update 2015. In: International soil classification system for naming soils and creating legends for soil maps. World soil resources reports no. 106. FAO, Rome

Jahn R, Blume HP, Asio V, Spaargaren O, Schad P (2006) Guidelines for soil description. FAO, Rome

Jandl R, Lindner M, Vesterdal L, Bauwens B, Baritz R, Hagedorn F, Johnson DW, Minkkinen K, Byrne KA (2007) How strongly can forest management influence soil carbon sequestration? Geoderma 137(3-4):253-268. https://doi. org/10.1016/j.geoderma.2006.09.003
Kasparinskis R, Astover A, Reintam E, Zelčš V, Nikodemus O, Kārklinš̌ A (2017) International WRB soil classification field workshop in Latvia and Estonia. University of Latvia, Estonian University of Life Sciences, Latvia and Estonia

Kukuls I, Nikodemus O, Kasparinskis R, Grāvelsina S, Prižavoite D (2015) Carbon accumulation and humufication in soils of abandoned former agricultural lands in the Hemiboreal zone. In: Zeverte-Rivza S (ed) "Nordic view to sustainable rural development", proceedings of the 25th NJF congress. NJF Latvia, Riga, pp 201-207

Laganière J, Angers DA, Parè D (2010) Carbon accumulation in agricultural soils after afforestation: a meta-analysis. Glob Chang Biol 16(1):439-453. https:// doi.org/10.1111/j.1365-2486.2009.01930.x

Li D, Niu S, Luo Y (2012) Global patterns of the dynamics of soil carbon and nitrogen stocks following afforestation: a meta-analysis. New Phytol 195(1): 172-181. https://doi.org/10.1111/j.1469-8137.2012.04150.x

MacDonald GK, Bennett EM, Taranu ZE (2012) The influence of time, soil characteristics, and land-use history on soil phosphorus legacies: a global meta-analysis. Glob Chang Biol 18(6):1904-1917. https://doi.org/10.1111/j. 1365-2486.2012.02653.x

Mao R, Zeng D-H, Hu Y-L, Li L-J, Yang D (2010) Soil organic carbon and nitrogen stocks in an age-sequence of poplar stands planted on marginal agricultural land in Northeast China. Plant Soil 332(1):277-287. https://doi.org/10.1007/ s11104-010-0292-7

Miletić Z, Knezevic M, Stajic S, Košanin O, Dordevic I (2012) Effect of European black Alder monocultures on the characteristics of reclaimed mine soil. Int J Environ Res 6:703-710

Morozov G, Aosaar J, Varik M, Becker H, Lõhmus K, Padari A, Aun K, Uri V (2018) Long-term dynamics of leaf and root decomposition and nitrogen release in a grey alder (Alnus incana (L.) Moench) and silver birch (Betula pendula Roth. ) stands. Scand J Forest Res 34:12-25. https://doi.org/10.1080/02827581.2018. 1521468

Paul Kl, Polglase PJ, Nyakuengama JG, Khanna PK (2002) Change in soil carbon following afforestation. Forest Ecol Manag 168(1):241-257. https://doi.org/10. 1016/S0378-1127(01)00740-X

Podwika M, Solek-Podwika K, Ciarkowska K (2018) Changes in the properties of grassland soils as a result of afforestation. iForest 11:600-608. https://doi.org/ 10.3832/ifor2556-011

Preem J-K, Truu J, Truu M, Mander Ü, Oopkaup K, Lõhmus K, Helmisaari H-S, Uri $V$, Zobel M (2012) Bacterial community structure and its relationship to soil physico-chemical characteristics in alder stands with different management histories. Ecol Eng 49:10-17. https://doi.org/10.1016/j.ecoleng.2012.08.034

Prishchepov AV, Radeloff VC, Baumann M, Kuemmerle T, Müller D (2012) Effects of institutional changes on land use: agricultural land abandonment during the transition from state-command to market-driven economies in postsoviet Eastern Europe. Environ Res Lett 7(2):024021. https://doi.org/10.1088/ 1748-9326/7/2/024021

Ross DJ, Tate KR, Scott NA, Feltham CW (1999) Land-use change: effects on soil carbon, nitrogen and phosphorus pools and fluxes in three adjacent ecosystems. Soil Biol Biochem 31(6):803-813. https://doi.org/10.1016/S00380717(98)00180-1

Ruskule A, Nikodemus O, Kasparinskis R, Prižavoite D, Bojāre D, Brūmelis G (2016) Soil-vegetation interactions in abandoned farmland within the temperate region of Europe. New Forest 47:587-605. https://doi.org/10.1007/s11056016-9532-x

Skyllberg U (1996) Small scale pH buffering in organic horizons of two boreal coniferous forest stands. Plant Soil 179(1):99-107

Taleshi SAR, Dhumal KN, Alipour A, Espahbodi K, Ghasemi O (2009) Impact of alder (Alnus subcordata) in fertility of forest soil. Res J Environ Sci 3:640-644. https://doi.org/10.3923/rjes.2009.640.644

Tan KH (2005) Soil sampling, preparation, and analysis, 2nd edn. CRC Press, New York

Uliassi DD, Ruess RW (2002) Limitaions to symbiotic nitrogen fixation in primary succession on the Tanana river floodplain. Ecology 83(1):88-103. https://doi. org/10.1890/0012-9658(2002)083[0088:LTSNFI]2.0.CO;2

Uri V, Aosaar J, Varik M, Becker H, Ligi K, Padari A, Kanal A, Lõhmus K (2014) The dynamics of biomass production, carbon and nitrogen accumulation in grey alder (Alnus incana (L.) Moench) chronosequence stands in Estonia. Forest Ecol Manag 327:106-117. https://doi.org/10.1016/j.foreco.2014.04.040

Uri V, Kukumägi M, Aosaar J, Varik M, Becker H, Soosaar K, Morozov G, Ligi K, Padari A, Ostonen I, Karoles K (2017) Carbon budgets in fertile grey alder (Alnus incana (L.) Moench.) stands of different ages. Forest Ecol Manag 396: 55-67. https://doi.org/10.1016/j.foreco.2017.04.004 
Uri V, Löhmus K, Mander Ü, Ostonen I, Aosaar J, Maddison M, Helmisaari H-S, Augustin J (2011) Long-term effects on the nitrogen budget of a shortrotation grey alder (Alnus incana (L.) Moench) forest on abandoned agricultural land. Ecol Eng 37(6):920-930. https://doi.org/10.1016/J.ECOLENG. 2011.01 .016

Uri V, Tullus H, Lõhmus K (2003) Nutrient allocation, accumulation and aboveground biomass in grey alder and hybrid alder plantations. Silva Fenn 37(3): 301-311

van Reeuwijk LP (1995) Procedures for soil analysis. ISRIC, Wageningen Vanmechelen L, Groenemans R, Van Ranst E (1997) Forest soil condition in Europe: results of a large-scale soil survey. In: Forest soil co-ordinating Centre in co-op. eith the Ministry of the Flemish Community. EC: UN/ECE, Brussels, Geneva, p 261

\section{Submit your manuscript to a SpringerOpen ${ }^{\circ}$ journal and benefit from:}

- Convenient online submission

- Rigorous peer review

- Open access: articles freely available online

- High visibility within the field

- Retaining the copyright to your article

Submit your next manuscript at $\boldsymbol{\nabla}$ springeropen.com 